\title{
The potential impacts of climate change on the mid-A tlantic coastal region
}

\author{
Raymond G. N ajjar ${ }^{1, *}$, Henry A. Walker ${ }^{2}$, Patti J. Anderson ${ }^{3}$, Eric J. Barron 4 , \\ Richard J . Bord ${ }^{5}$, J ody R. G ibson ${ }^{6}$, Victor S. Kennedy ${ }^{7}$, C. Gregory Knight ${ }^{8}$, \\ J. Patrick Megonigal ${ }^{9}$, Robert E. $0^{\prime}$ C onnor $^{10}$, Colin D. Polsky ${ }^{8}$, N orbert P. Psuty ${ }^{11}$, \\ Bruce A. Richards ${ }^{12}$, Lisa G. Sorenson ${ }^{13}$, Eric M. Steele ${ }^{8}$, Robert S. Swanson ${ }^{1}$ \\ ${ }^{1}$ Department of M eteorology, ${ }^{3}$ Environmental Resources Research Institute, ${ }^{4}$ The Environment Institute, \\ ${ }^{5}$ Department of Sociology, ${ }^{6}$ Department of G eosciences, ${ }^{8}$ Department of G eography, and \\ ${ }^{10}$ Department of Political Science, The Pennsylvania State University, University Park, Pennsylvania 16802, USA \\ ${ }^{2}$ A tlantic Ecology Division, N ational Health and Environmental Effects Research Laboratory, \\ US Environmental Protection Agency, 27 Tarzwell Drive, Narragansett, Rhode Island 02882, USA \\ ${ }^{7}$ Horn Point Laboratory, University of M aryland Center for Environmental Science, \\ 2020 HornsPoint Rd, C ambridge, M aryland 21613, USA \\ ${ }^{9}$ Department of Biology, G eorge M ason University, Fairfax, Virginia 22030-4444, USA \\ ${ }^{11}$ Institute of M arine and C oastal Sciences, 71 Dudley Road, Rutgers University, C ook Campus, \\ New Brunswick, N ew Jersey 08901, USA \\ ${ }^{12}$ Delaware C enter for the Inland Bays, 467 Highway One, Lewes, Delaware 19969, USA \\ ${ }^{13}$ Department of Biology, Boston University, 5 C ummington Street, Boston, M assachusetts 02215, USA
}

\begin{abstract}
This paper assesses the potential impacts of climate change on the mid-Atlantic coastal (MAC) region of the United States. In order of increasing uncertainty, it is projected that sea level, temperature and streamflow will increase in the MAC region in response to higher levels of atmospheric $\mathrm{CO}_{2}$. A case study for Delaware based on digital elevation models suggests that, by the end of the 21st century, $1.6 \%$ of its land area and $21 \%$ of its wetlands will be lost to an encroaching sea. Sea-level rise will also result in higher storm surges, causing $100 \mathrm{yr}$ floods to occur 3 or 4 times more frequently by the end of the 21st century. Increased accretion in coastal wetlands, however, which may occur in response to increases in $\mathrm{CO}_{2}$, temperature, and streamflow, could mitigate some of the flooding effect of sea-level rise. Warming alone will result in northward displacements of some mobile estuarine species and will exacerbate the already low summer oxygen levels in mid-Atlantic estuaries because of increased oxygen demand and decreased oxygen solubility. Streamflow increases could substantially degrade water quality, with significant negative consequences for submerged aquatic vegetation and birds. Though climate change may have some positive impacts on the MAC region, such as increased coastal tourism due to warming and some ecological benefits from less-frequent harsh winters, most impacts are expected to be negative. Policies designed to minimize adverse ecological impacts of human activities on coastal ecosystems in the mid-Atlantic, such as decreases in nutrient loading of watersheds, could help mitigate some of the risks associated with future climate variability and change in this region.
\end{abstract}

KEY WORDS: Climate change impacts · Coastal regions - Sea-level rise

\section{INTRODUCTION}

Impacts of climate change on coastal regions will have a regional signature that depends on the local cli-

*E-mail: najjar@essc.psu.edu mate change and the local geomorphological, biogeochemical, ecological and social factors that affect the sensitivity to climate. Here we present an assessment of the potential impacts of climate change on one of the most populated and ecologically important areas of the United States, the mid-Atlantic coastal (M AC) region, 
as part of a 'National Assessment' process mandated by the US Global Change Research Program (Fisher et al. 2000, in this issue). For this assessment, the MAC region extends from central $\mathrm{New}$ J ersey (near Toms River) to central North Carolina (near Cape Lookout), and includes several large estuaries: Delaware Bay, Chesapeake Bay and Albemarle-Pamlico Sound (see Polsky et al. [2000, in this issue] for a map of the region). Our assessment is based partly on output from coupled ocean-atmosphere models developed at the Hadley Centre for Climate Prediction and Research and the Canadian Climate Centre (CCC) (Polsky et al. 2000). These models were run in a transient mode from the middle of the 19th century to the end of the 21st century with gradual increases in greenhouse gases (1\% $\mathrm{yr}^{-1} \mathrm{CO}_{2}$ equivalent) and sulfate aerosols (the 'IS92a' scenario, Houghton et al. 1996). For more details on the models, see J ohns et al. (1997), Mitchell et al. (1995), M itchell \& J ohns (1997), Boer et al. (1984, 1992, 2000a,b), Flato et al. (2000) and M cFarlane et al . (1992). Following National Assessment guidelines, we base our assessment on output from these models averaged over $10 \mathrm{yr}$ periods centered on 2030 and 2095, referenced to the climate of the $10 \mathrm{yr}$ period centered on 1990, except where noted.

The remainder of the paper is organized as follows: First we summarize how climate change is likely to affect the physical environment in the MAC region. We not only consider how sea level will change, but atmospheric $\mathrm{CO}_{2}$, temperature, precipitation and streamflow. Then we discuss the possible ecological and societal responses to such changes. We conclude by identifying priorities for climate-change research in the MAC region.

\section{CLIMATE-RELATED CHANGES IN THE PHYSICAL STATE OF THE MAC REGION}

\author{
2.1. Atmospheric $\mathrm{CO}_{2}$ concentration
}

Of the possible global changes in the physical environment of coastal regions, a rise in atmospheric $\mathrm{CO}_{2}$ is the most likely (Table 1). Though there is active debate about the necessity and feasibility of reducing $\mathrm{CO}_{2}$ emissions, the long lifetime of $\mathrm{CO}_{2}$ in the atmosphere means that $\mathrm{CO}_{2}$ levels will likely rise even in the face of the most stringent emission reductions ( $\mathrm{H}$ oughton et al. 1996). The best estimate is that atmospheric $\mathrm{CO}_{2}$ concentration will be approximately double its 1990 value by 2095 .

\subsection{Sea-level rise and coastal flooding}

Sea-level variations on time scales of a decade or more have 2 components: a global component that reflects thermal expansion of the ocean and glacial melting (eustatic sea-level rise) and a local component that reflects vertical land movements (resulting, for example, from regional tectonics, post-glacial isostatic adjustment, compaction and surface subsidence). The sum of the 2 components is known as relative sea-level rise (RSLR), which, over the past $100 \mathrm{yr}$, has been measured mainly from tide gauges. By avoiding regions of significant tectonic sea-level rise impacts and by accounting for post-glacial isostatic adjustment, Douglas (1991) estimated a eustatic sea-level rise of $1.8 \pm$

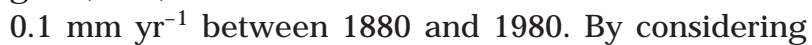
other studies, Warrick et al. (1996) gave a range of 1.0

Table 1. Mid-Atlantic coastal (M AC) region climate projections for 2030 and 2095 with respect to 1990

\begin{tabular}{|c|c|c|c|c|c|}
\hline \multirow[t]{2}{*}{ Parameter } & \multicolumn{2}{|c|}{2030} & \multicolumn{2}{|c|}{2095} & \multirow{2}{*}{$\begin{array}{c}\text { Reliability of } \\
\text { mean prediction }\end{array}$} \\
\hline & Mean & Range & Mean & Range & \\
\hline $\mathrm{CO}_{2}(\%)^{\mathrm{a}}$ & +25 & +20 to +30 & +92 & +52 to +118 & Very high \\
\hline (ppm) & +90 & +70 to +105 & +325 & +185 to +420 & \\
\hline Sea level $(\mathrm{cm})^{\mathrm{b}}$ & +19 & +11 to +31 & +66 & +39 to +102 & High \\
\hline Temperature $\left({ }^{\circ} \mathrm{C}\right)^{\mathrm{C}}$ & +1.3 & +1.0 to +1.5 & +4.0 & +2.7 to +5.3 & High \\
\hline Precipitation $(\%)^{c}$ & +4 & -1 to +8 & +15 & +6 to +24 & Medium \\
\hline Streamflow $(\%)^{d}$ & +2 & -2 to +6 & +11 & -4 to +27 & Low \\
\hline \multicolumn{6}{|c|}{$\begin{array}{l}\text { aM ean reflects IS92a and range reflects IS92d and IS92f } \mathrm{CO}_{2} \text { emission scenarios; see Fig. 5b from technical summary of } \\
\text { Houghton et al. (1996). } 1990 \mathrm{CO}_{2} \text { concentration was } 355 \text { ppm }\end{array}$} \\
\hline \multicolumn{6}{|c|}{$\begin{array}{l}\text { bow, middle and high projections of Warrick et al. (1996) for IS92a scenario with varying aerosols (see their Fig. 7.7), plus a } \\
\text { local component of } 2 \mathrm{~mm} \mathrm{yr}^{-1}\end{array}$} \\
\hline \multicolumn{6}{|c|}{$\begin{array}{l}\text { 'Range is given by Hadley Centre and Canadian Climate Centre (CCC) models for the mid-Atlantic region (Polsky et al. } \\
\text { 2000). M ean is average of } 2 \text { models. Changes are with respect to 1983-1994 model output }\end{array}$} \\
\hline${ }^{d}$ For the Susquehar & in, usino & ater balance $\mathrm{m}$ & & and Hadley outr & \\
\hline
\end{tabular}


to $2.5 \mathrm{~mm} \mathrm{yr}^{-1}$ for eustatic sea-level rise over the past century. In the mid-Atlantic region, RSLR is between 3 and $4 \mathrm{~mm} \mathrm{yr}^{-1}$ (Titus \& Narayanan 1995), suggesting a local component of RSLR of about $2 \mathrm{~mm} \mathrm{yr}^{-1}$, which may be due to variations in the accumulations of Holocene sediments and their subsequent compaction (Psuty 1992, Nicholls \& Leatherman 1996), regional differential crustal warping (Walker \& Coleman 1987) and possibly removal of groundwater by humans (Leatherman et al. 1995). Kearney \& Stevenson (1991) noted that around Chesapeake Bay, relatively rapid RSLR during the 19th century contrasts with slower RSLR during the 17th and 18th centuries, a period of cooler global conditions. They also note that 19th-century global warming and eustasy are insufficient to account for the magnitude of the recent acceleration in RSLR around Chesapeake Bay. The effects of groundwater withdrawals and recent alterations in sediment loading need to be evaluated to fully understand local changes (Kearney \& Stevenson 1991).

The rate of eustatic sea-level rise is likely to increase in the future because of $\mathrm{CO}_{2-}$ induced warming, which will cause expansion of the ocean and possibly glacial melting. The best estimate of Warrick et al. (1996) is that, by 2030 and 2095, global sea level will be about 11 and $45 \mathrm{~cm}$ higher, respectively, than in 1990. Adding in a local RSLR of $2 \mathrm{~mm} \mathrm{yr}^{-1}$, these figures increase to 19 and $66 \mathrm{~cm}$, respectively, for MAC waters (Table 1). For the MAC region, therefore, global climate change, as opposed to local effects, is predicted to account for about 60 and $70 \%$ of the sealevel change from 1990 to 2030 and 2095, respectively.

How much land will be lost as a result of sea-level rise in the MAC region? We are currently using digital elevation models (DEM s) to assess this and here we present the results for Delaware. A simple inundation model was used in which all land with an elevation less than $61 \mathrm{~cm}$ is assumed to be flooded. ${ }^{1}$ We acquired DEM $\mathrm{s}$ in $7.5 \mathrm{~min}$ maps with a horizontal resolution of $30 \mathrm{~m}$ from the United States Geological Survey (USGS, detailed information on the data

${ }^{1}$ The DEMs give elevation in integral feet. A value of $1 \mathrm{ft}$, for example, is assumed to represent land between sea level and $1 \mathrm{ft}$ above sea level. For the calculation, we chose a sea-level rise of $2 \mathrm{ft}(61 \mathrm{~cm})$, which is the value closest to $66 \mathrm{~cm}$, the projected rise for 2095 set is available from USGS 1999a). We estimate that $91 \mathrm{~km}^{2}$ (22000 acres) would be inundated, or about $1.6 \%$ of the total land area of the Delaware (Fig. 1). There are 2 factors that make this calculation an underestimate. First, the DEMs are derived by digitizing topographic maps with coarse contour intervals, normally around $10 \mathrm{ft}(3 \mathrm{~m})$, using linear interpolation to fill in values between contour lines. Because shorelines in the MAC region are typically concave-up (i.e. the slope increases in the inland direction), the DEMs underestimate the amount of low-lying land nearshore. Second, we have completely ignored erosion at the shoreface, which will increase the amount of inundation (Bruun 1988). Other factors that could bias our calculation, such as the delivery of sediment from rivers
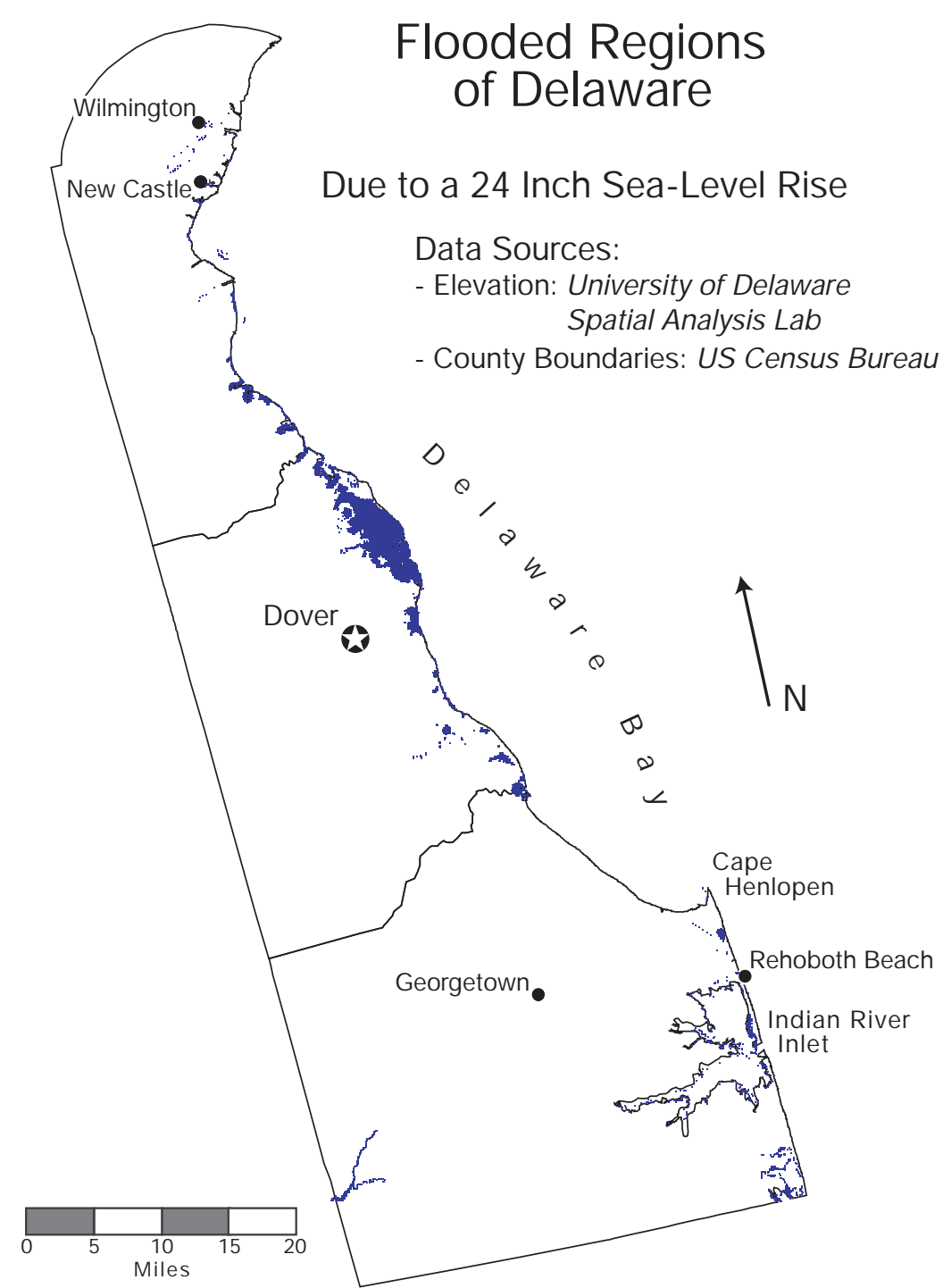

Fig. 1. Inundation of the shoreline of Delaware due to a rise in sea level of $61 \mathrm{~cm}$ ( $2 \mathrm{ft}$ ). See text for details of calculation 


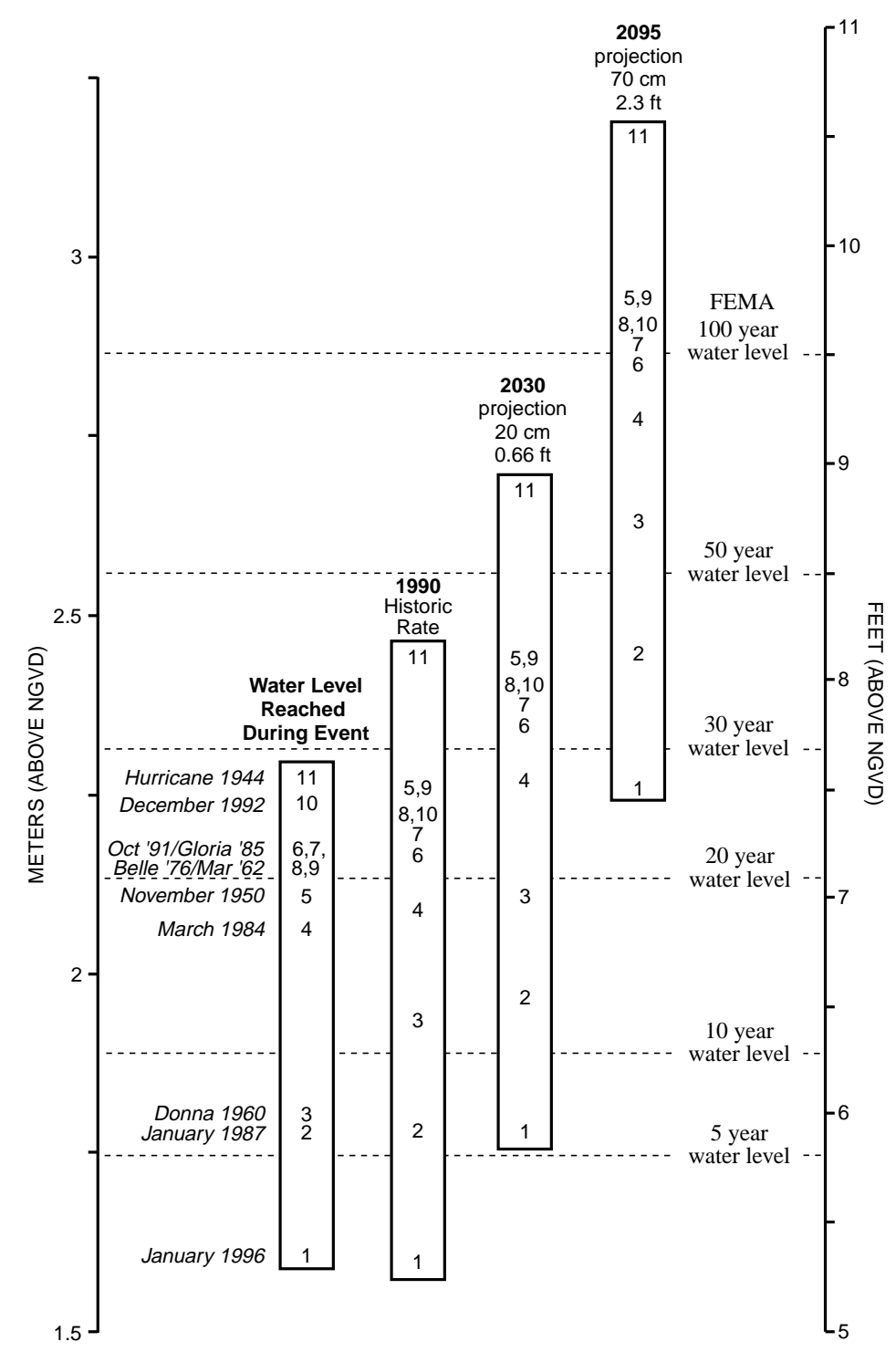

Fig. 2. Impact of sea-level rise on storm-surge-level recurrence intervals at Atlantic City, New J ersey. Recurrence-interval values (horizontal lines) are current Federal Emergency Management Agency (FEMA) determinations for Atlantic City. The vertical axis is height above the fixed elevation known as the National Geodetic Vertical Datum (NGVD). The first column on the left is the storm-surge level achieved during the specific event. Each event has a corresponding number repeated in the remaining columns. The second column shows the flood levels these storms would have produced had they occurred in 1990, using a sea-level rise of $3.85 \mathrm{~mm} \mathrm{yr}^{-1}$. The third and fourth columns show the expected flood level of these storms given a sea-level increase of $20 \mathrm{~cm}$ and $70 \mathrm{~cm}$, the best estimates for 2030 and 2095, respectively storm, which had a probability slightly greater than 1-in-20 yr. If that storm had occurred in 1990, its flood level would have been $11 \mathrm{~cm}$ higher, assuming a $3.85 \mathrm{~mm} \mathrm{yr}^{-1}$ rate of sea-level rise, the average over the past 85 yr (Psuty \& Collins 1996). Such a flood has nearly a 1-in-30 yr probability. If the storm were to occur in 2030, when sea level is expected to be about $20 \mathrm{~cm}$ higher than in 1990 , it would produce a flood considered to have a 1-in-40 yr probability. For 2095, when sea level is expected to be about $70 \mathrm{~cm}$ higher than in 1990, it would produce a flood considered to have a 1-in-120 yr probability. These calculations suggest that coastal flooding due to storms will be much more severe by the end of the 21st century than they are today.

\subsection{Temperature}

The prediction of rising air temperature in the MAC region is less certain than the sealevel rise prediction because regional responses of climate are harder to predict and the cooling impact of aerosols may offset the $\mathrm{CO}_{2}$-induced warming. This cooling impact is likely to be significant in the mid-Atlantic region because of its high industrial activity, though the implementation of new environmental regulations would reduce the impact. Uncertainties are reflected in the range of the predictions of the 2 climate models used for the National Assessment (Table 1; see also Polsky et al. 2000).

How will MAC water temperatures respond? Using data from the Chesapeake Bay Program, we computed monthly mean temperature from 1949 to 1994 in 23 regions of the main-stem Chesapeake Bay, using techniques described by Gibson \& Najjar (unpubl.). We found Bay temperature to be highly correlated ( $r^{2}$ from 0.68 to 0.93 ) with the estimation of mean surface air temperature over the Susquehanna River Basin (Najjar 1999). The slopes of the linear fits vary from 0.99 in shallow waters to 0.68 in deep waters, showing that water temperatures in Chesapeake Bay, and probably in most estuaries and coastal bays in the region, closely track air temperature. This suggests that the warming of surface air masses in the northeastern US will be tracked by nearshore MAC waters. During the summer, water temperatures in shallow areas may increase less than air temperatures as a result of evaporative cooling. In deeper, and organic matter accumulation in the root zone of marshes, are taken up in a later section.

Storm-surge levels will be affected by sea-level rise, even if the frequency and intensity of storms do not change. To illustrate this, past storm events in Atlantic City, NJ , are adjusted to the 1990 sea level and projected to 2030 and 2095 (Fig. 2). Consider the 1962 
less-restricted MAC waters, the temperature change is likely to be smaller because of the greater volume to be heated and the larger influence of ocean circulation and mixing (Williams \& Godshall 1977).

\subsection{Precipitation}

The $2 \mathrm{~N}$ ational Assessment models predict increases in mean precipitation over the northeastern US by 2095 (Table 1). Such predictions are supported by other climate model studies in the mid-Atlantic (Hodny 1992, Crane \& Hewitson 1998, Najjar 1999). Estimates of the magnitude and seasonal timing of the precipitation increase vary considerably among models, suggesting significant uncertainty in these predictions. The combined effect of higher sea level and more precipitation would very likely result in greater coastal flooding.

\subsection{Streamflow}

Streamflow into coastal waters, which responds to air temperature and precipitation, is an extremely important driver of variability in mid-Atlantic estuaries. Neff et al. (2000, in this issue) showed that very different changes in streamflow are predicted by a water balance model when forced by the output of the 2 National Assessment climate models; this is because of the counteracting effects of increasing temperature and precipitation (Table 1). Three published studies on the response of mid-Atlantic streamflow to a doubling of atmospheric $\mathrm{CO}_{2}$ reinforce this uncertainty ( $\mathrm{M}$ cCabe \& Ayers 1989, Moore et al. 1997, Najjar 1999). In the future, other factors may also affect the amount of streamflow into coastal waters. Elevated $\mathrm{CO}_{2}$ may decrease evapotranspiration on land, thereby increasing streamflow (Wigley \& Jones 1985). Increased urbanization will increase the fraction of land that is impervious to water infiltration, resulting in increased runoff and streamflow (DeWalle et al. unpubl.). The combined uncertainty of the effects of precipitation, temperature, $\mathrm{CO}_{2}$, and urbanization on streamflow makes prediction extremely uncertain.

\section{ECOLOGICAL RESPONSES}

\subsection{Coastal wetlands}

Coastal wetlands include wetland forests, saltwater marshes and freshwater marshes. These wetlands serve several important functions: wildlife habitats; spawning grounds; filtration systems for excess nutri- ents (from agricultural runoff and acid rain), heavy metals, and organic toxic substances (e.g. pesticides); and recreational open space. Sea-level rise is likely to be the most important climate-related impact on coastal wetlands. To evaluate the potential for this impact, we return to the Delaware case study (Fig. 1). To characterize land-use, we use maps from the MultiResolution Land Characteristics (M RLC) Consortium, which are based on Landsat Thematic Mapper data (USGS 1999b). The data are available at the same resolution as the DEM s described earlier and are based on the land use characteristics of 1993 . We find that most of the affected area is wetlands-95\% marsh and $1 \%$ forest-and estimate that $21 \%$ of all marsh land in Delaware will be flooded.

The potential for future horizontal migration inland by wetland plant species is limited primarily by human barriers, such as urban and suburban development and the construction of seawalls and bulkheads. Less than $1 \%$ of the affected area in Fig. 1 is currently developed, suggesting that future horizontal migration may be possible in Delaware if urbanization is controlled. However, direct anthropogenic modifications, including causeway construction, which alters tidal flushing, and creation and maintenance of mosquito ditches, can alter salt marsh vegetation patterns and processes (Niering \& Warren 1980).

Wetlands can accrete vertically, depending on the availability of sediment and the rate of organic matter accumulation within the root zone, potentially reducing the flooding effect of sea-level-rise. The amount of land lost for a given length of shoreline will be a reflection of the deficit of sediment and organic matter inputs with respect to the increased volume of water associated with sea-level rise. As noted earlier, Chesapeake Bay salt marshes currently do not receive sufficient sediment and organic matter to keep up with current rates of sea-level rise (Stevenson et al. 1988, Kearney \& Stevenson 1991). It seems likely that the current imbalance will grow in the future because sealevel rise rates are projected to increase and because the decreasing trend in sediment yields of major midAtlantic rivers over the past few decades is likely to continue. The latter is largely a result of farmland abandonment, dam construction and reduced soil erosion (Trimble 1974, M eade 1982).

Because of the importance of sediment inputs, M AC wetlands will not respond uniformly to sea-level rise. Thus, those wetlands lacking inputs of riverine sediments will be most vulnerable to sea-level rise. These wetlands include microtidal marshes of the Chesapeake Bay, extensive non-tidal wetlands of the Albermarle-Pamlico Peninsula (M oorhead \& Brinson 1995), and upland and marsh islands in Chesapeake Bay. Wray et al. (1995) noted that upland islands along the 
main stem of Chesapeake Bay are rapidly eroding, due to wave action against low silt/clay cliffs, and are expected to totally disappear in fewer than $20 \mathrm{yr}$. $M$ arsh islands in Chesapeake Bay are shrinking due to perimeter edge erosion and interior marsh loss, and are likely to be greatly reduced in size or totally lost in the coming century (Wray et al. 1995).

On the other end of the spectrum are tidal freshwater marshes, which receive large influxes of riverine sediments, and so are likely to be less vulnerable to sea-level rise than their saltwater counterparts. However, horizontal migration of these wetlands will be limited by the steep valley slopes that characterize the upper reaches of such river systems, and up-river migration will be limited by increasingly narrow channels. Conversely, an increase in freshwater flow would shift tidal freshwater wetlands downstream, potentially increasing their area.

Climate-related changes in the environment may affect the material balance in wetlands, thereby affecting the degree of flooding due to sea-level rise. This could happen in at least 3 ways. First, carbon storage in wetlands may be altered by elevated $\mathrm{CO}_{2}$. A M aryland salt marsh exposed to experimentally doubled levels of $\mathrm{CO}_{2}$ (with respect to ambient) since 1987 has responded with an increase in carbon storage, mainly below ground (Drake et al. 1996). Because the marsh in this study is isolated from a number of geophysical and biogeochemical processes that affect soil aggregation on regional scales, it is uncertain whether these results can be applied regionally. Second, regional warming may influence carbon storage in marsh sediments. A trend for higher levels of soil organic matter in Gulf-of-M exico marshes compared to northern marshes (Callaway et al. 1996) suggested that the net effect of regional warming will be to increase accretion rates. Also, the effect of elevated $\mathrm{CO}_{2}$ on net ecosystem production increases with temperature by about $2 \%$ ${ }^{\circ} \mathrm{C}^{-1}$ (Drake et al. 1996). Third, and last, if streamflow and streamflow variability increase [as a result of increases in precipitation and precipitation variability (Table 1)], then riverine inputs of sediments to marshes would likely increase.

Thus, all 3 of these climate-related changes $\left(\mathrm{CO}_{2}\right.$, temperature and hydrology) have the potential to reduce some of the flooding effect of sea-level rise in coastal wetlands. Quantifying these effects, however, is extremely difficult. With regard to the impacts of hydrology, they are difficult to quantify mainly because of the uncertainty in the precipitation predictions. With regard to organic matter accumulation rates, very little is known about their theoretical maximum upper limits and to what extent accretion results in an increase in surface elevation. For example, Bricker-Urso et al. (1989) suggested a maximum theo- retical accretion rate of $16 \mathrm{~mm} \mathrm{yr}^{-1}$, a rate that exceeds even the highest projections for the mid-Atlantic, but Cahoon et al. (1995) found that surface elevation changes in microtidal marshes in the southeastern US were significantly less than vertical accretion rates. Clearly, more work is needed on the potential for increased accretion in the root zone as a function of $\mathrm{CO}_{2}$ and temperature increases, particularly in the context of local elevation changes due to subsurface subsidence.

In addition to RSLR and resulting changes in vegetation patterns, elevated $\mathrm{CO}_{2}$ in the marsh study described above significantly increased the density of C 3 species (e.g. sedge Scirpus ol neyi) at the expense of C 4 species (e.g. grasses Spartina patens and Distichlis spicata) (Drake et al. 1996). Thus, elevated $\mathrm{CO}_{2}$ may change plant species composition in coastal marshes. The cumulative consequences of such changes on ecosystem functioning are uncertain.

\subsection{C oastal bays and estuaries}

\subsubsection{Salinity}

As sea level rises, the ocean will encroach landward and estuarine salinity will increase. Hull \& Titus (1986) suggest that such a salinity change could have significant negative impacts on drinking water quality and estuarine ecosystems in and around Delaware Bay during the 21st century. They used a 1-dimensional numerical model to evaluate the impact of a $73 \mathrm{~cm}$ sealevel rise (expected near the end of the 21st century, Table 1) on salinity above a 1965 baseline. The maximum $30 \mathrm{~d}$ average chloride concentration increased from 135 to $305 \mathrm{mg} \mathrm{l}^{-1}$ (average seawater is about $20000 \mathrm{mg} \mathrm{l}^{-1}$ ) at one location in the upper Bay. The salt front (a rapid change in salinity in the horizontal direction, which is indicated by a chloride concentration of $250 \mathrm{mg} \mathrm{l}^{-1}$ in this Bay) was predicted to move upstream by $11 \mathrm{~km}$.

In addition to sea-level variations, streamflow affects estuarine salinity on interannual timescales. Drought conditions in late 1964 caused the Delaware Bay salt front to advance up to $50 \mathrm{~km}$ upstream with respect to its average position (Hull \& Titus 1986). To investigate streamflow impacts on Chesapeake Bay salinity, Gibson \& Najjar (unpubl.) developed an autoregressive statistical model with monthly resolution. They found that annual mean salinity decreases by $0.8 \%$ in the upper Bay to $0.1 \%$ in the lower Bay for every $1 \%$ increase in annual mean streamflow. We applied the Gibson \& Najjar (unpubl.) model to the streamflow projections by $\mathrm{Neff}$ et al. (2000), which were derived using output from the National Assessment climate 
models. For the CCC model, the mid-Bay salt front is projected to migrate upstream by $3 \mathrm{~km}(0.94 \%$ of the Bay's length) by 2030 and $7 \mathrm{~km}$ (2.2\% of the Bay's length) by 2095. For the Hadley model, the mid-Bay salt front is projected to migrate downstream by $11 \mathrm{~km}$ (3.4\% of the Bay's length) by 2030 and $48 \mathrm{~km}$ (15\% of the Bay's length) by 2095. Clearly, streamflow changes could either offset or compound the effects of sea-level rise on the salinity of MAC waters.

\subsubsection{Water quality, plankton and submerged aquatic vegetation}

Current water-quality conditions in mid-Atlantic estuaries are typically poor. According to NOAA (1997a,b) and US EPA (1998), mid-A tlantic estuaries are generally characterized as high in chlorophyll concentration (a measure of phytoplankton abundance), nutrients and turbidity, and low in submerged aquatic vegetation (SAV) and dissolved oxygen. A significant increase of phytoplankton biomass has occurred during the last 40 to 50 yr in M AC waters; the increase in Chesapeake Bay has been particularly well documented (Harding \& Perry 1997). Nuisance algae are reported for half of the mid-Atlantic estuaries and toxic algal blooms have had resource impacts in 4 bays, 3 of which are in North Carolina (NOAA 1997a,b). US EPA (1998) identified Chesapeake Bay as the most hypoxic estuary in the region, with low dissolved oxygen levels associated with stratification and nutrient overenrichment.

How will climate change influence mid-Atlantic estuarine water quality, plankton, and SAV? The single most important climatic influence on estuarine water quality is streamflow. For several reasons, water quality degrades as streamflow increases (Hurley 1991). First, the vertical stability of the water column increases as fresher water overrides denser saltier water, decreasing the ability of winds and tides to vertically mix water, thereby decreasing the replenishment of oxygen from the atmosphere to deeper waters of the estuary. Second, nutrient inputs from associated watersheds increase, increasing plankton production and the rain of organic debris to deeper levels, causing additional oxygen consumption as bacteria and other fauna degrade the debris. Third, increased particle loads in shallow areas may hinder filter feeding by invertebrates and cause water clarity and photosynthesis by SAV to decrease. Fourth, increased nutrient loading (and warming) stimulates growth in epiphytic algae on the blades of the SAV, reducing the light available to the SAV. Losses in SAV and their physical buffering of wave action along shorelines can contribute to increases in coastal erosion, which may further decrease water clarity.

Because of its impact on mid-A tlantic fisheries, the degree of anoxia in Chesapeake Bay is an important water-quality indicator. Seliger \& Boggs (1988) found that summertime anoxic volume in Chesapeake Bay in recent decades was highly correlated with A pril-May flow of the Susquehanna River, a major source of fresh water to the Bay. Their analysis suggests that a $10 \%$ increase in flow results in a $26 \%$ increase in summertime anoxic volume. The fact that anoxia depends on the timing, as well as the magnitude, of streamflow makes prediction under climate change difficult. Table 2 highlights this point by summarizing how climate-induced changes in streamflow may change Chesapeake Bay anoxia in the future. In addition to the $2 \mathrm{~N}$ ational Assessment models, results from 2 regional climate models are used. The results show that anoxia changes could be very large but the direction of the change varies among the different climate models. Walker et al. (2000) documented how anthropogenic activity has dramatically altered the relationship between nutrient flux and streamflow during the last century. They suggested that the relationship between Chesapeake Bay anoxia and streamflow documented by Seliger \& Boggs (1988) was much stronger in the past few decades than it was in previous centuries. If nutrient loads to the coast continue to increase as coastal populations grow, it seems that anoxia will become even more sensitive to streamflow in many mid-Atlantic estuaries.

Table 2. Change in A pril-M ay flow of the Susquehanna River and Chesapeake Bay summertime anoxic volume estimated from climate model output. CCC $=$ Canadian Climate Centre

\begin{tabular}{|c|c|c|c|c|c|c|}
\hline Change & $\begin{array}{l}\text { Hadley } \\
2030\end{array}$ & $\begin{array}{l}\text { CCC } \\
2030\end{array}$ & $\begin{array}{l}\text { Hadley } \\
2095\end{array}$ & $\begin{array}{l}\text { CCC } \\
2095\end{array}$ & $\begin{array}{c}\text { Nested model }^{\mathrm{a}} \\
2 \times \mathrm{CO}_{2}\end{array}$ & $\begin{array}{l}\text { Empirical downscaling }^{\mathrm{b}} \\
\qquad 2 \times \mathrm{CO}_{2}\end{array}$ \\
\hline $\begin{array}{l}\text { April-M ay flow }(\%)^{c} \\
\text { Anoxic volume }(\%)^{d}\end{array}$ & $\begin{array}{l}+12 \\
+31\end{array}$ & $\begin{array}{r}-4 \\
-10\end{array}$ & $\begin{array}{r}+4 \\
+10\end{array}$ & $\begin{array}{l}-25 \\
-65\end{array}$ & $\begin{array}{r}+43 \\
+112\end{array}$ & $\begin{array}{l}-0.2 \\
-0.5\end{array}$ \\
\hline \multicolumn{7}{|c|}{$\begin{array}{l}\text { aDetails of these models are given in Crane \& Hewitson (1998) and Najjar (1999) } \\
\text { bSee Crane \& Hewitson (1998) for details of precipitation calculation. Temperature taken from Hadley } 2095 \\
\text { 'C } 0 \text { pomputed from water balance model of Najjar (1999). Also see N eff et al. (2000) } \\
\text { dUses linear relationship of Seliger \& Boggs (1988) }\end{array}$} \\
\hline
\end{tabular}


The oxygenation of estuarine waters will be affected by warming. For each ${ }^{\circ} \mathrm{C}$ that water warms, oxygen solubility (the capacity to dissolve oxygen) decreases by about $2 \%$. Changes in oxygen concentration also depend on biotic factors. Higher temperature increases bacterial production and raises the metabolism of coldblooded aquatic animals (invertebrates, amphibians, fish and reptiles), thereby increasing the metabolic need for oxygen. Thus, warming will increase anoxia in MAC waters, but the magnitude of the effect is not known.

Increases in water temperature are likely to have important effects on phytoplankton species composition, their geographic range, and grazing rates of their zooplankton and benthic filter- feeding predators. Several species of toxic phytoplankton enjoy wider distribution during warmer periods (Tester 1996). Keller et al. (1999) demonstrated that increases in winter temperature can result in increased cropping of phytoplankton by zooplankton in the water column, reducing the supply of detrital material for benthic organisms. This could negatively impact benthic food chains, but have a positive effect on the oxygenation of bottom waters.

\subsection{Fish and shellfish}

Variations in the abundance of many fish and shellfish are correlated with environmental conditions during early larval stages that affect natural mortality. Such variations subsequently affect variations in fishing mortality. H. Austin \& R. Wood (Virginia Institute of $M$ arine Sciences, pers. comm.) summarized fluctuations in recruitment patterns of Chesapeake Bay fish in relation to variations in weather and climate during the past several decades. Recruitment success in anadromous species was associated with variations in river discharge, whereas recruitment in bay-spawned species was influenced by wind, river discharge and temperature. Shallow-water spawners were sensitive to variability in precipitation and sea level during critical periods. Recruitment in many shelf-spawned species was associated with variability in winds on the coastal shelf. Thus, a combination of heavy fishing pressure and a series of climatically unfavorable years for recruitment can result in dramatic reductions in the abundance of valued fish stocks.

There is a historical basis for expecting warming to have significant impacts on estuarine and marine fish and shellfish in the mid-Atlantic. For example, M urawski (1993) found that marine temperature variation on the North American east coast explained changes in the north-south distribution of 12 of 36 species of fish. On the west coast from the early 1930 s to the mid 1990s, annual mean shoreline temperature increased by $0.75^{\circ} \mathrm{C}$, while abundances of $63 \%$ of northern species of rocky intertidal invertebrates decreased and $89 \%$ of southern species increased (Barry et al. 1995). Species whose southern range ends in the MAC region, such as the soft clam Mya arenaria in Chesapeake Bay, may be eliminated if water temperatures reach levels that are lethal or that inhibit successful reproduction. Such losses could initially reduce local estuarine diversity because species are often more readily eliminated from an estuarine environment than replaced (Kennedy 1990). On the other hand, a positive impact of warming might be less frequent severe winters, like the severe winters of 1977 and 1981, which are thought to have resulted in low blue crab Callinectes sapidus catches in the Delaware estuary (US EPA 1998).

Parasitic and predatory relationships among organisms in M AC waters are also sensitive to temperature. The parasite that causes Dermo disease in eastern oysters Crassostrea virginica was restricted to locations south of Delaware Bay before 1990. Since then, a rapid range expansion of this parasite to the north has occurred in association with warmer winters (Cook et al. 1998). Links between climate change and other marine diseases have been reviewed by Harvell et al. (1999). Experiments in Oregon have shown that small changes in sublethal temperatures interfere with the controlling effect of a starfish on its mussel prey, thereby potentially altering species compositions and dynamics of the intertidal community (Sanford 1999). Thus small, nonlethal temperature changes can indirectly cause large ecological changes.

The interactions between higher temperatures and depleted oxygen noted earlier could constrict the available habitat for a variety of species along the North American east coast, including striped bass Morone saxatilis in Chesapeake Bay, an important spawning center for this species (Coutant 1990). Laboratory studies have shown that organisms under stress pay a metabolic cost in the form of a continued expenditure of energy that may preclude survival if the stress does not abate (e.g. Parsons 1990). Examples of this in Chesapeake bay are shellfish mortalities that have occurred due to low-oxygen conditions (Officer et al. 1984, Seliger et al. 1985).

Climate-related salinity changes also could affect mid-Atlantic estuarine ecosystems. Sea-level rise will enable mobile estuarine species to migrate upstream, where potential impacts from pollution and other human influences will be greater. Higher salinities could result in the invasion of salinity-tolerant pests, such as 2 lethal oyster diseases and 2 species of predatory snails of eastern oysters that are inhibited by salinities below about 12 and 20, respectively (Kennedy \& Breisch 1981). During the mid-1980s, for example, low 
riverine flows resulting from low precipitation over the watersheds of mid-Atlantic states caused estuarine salinities to be higher than normal. Oyster diseases responded positively to these saltier waters and decimated the oyster population in much of the region (US EPA 1998). The predicted increases in streamflow (Table 1), on the other hand, may benefit oysters by making estuarine waters fresher and a poorer environment for disease. But if precipitation variability increases as predicted (Table 1), oysters and organisms with similar salinity thresholds may suffer. For example, the tremendous freshening of Chesapeake Bay associated with Tropical Storm Agnes in 1972 caused massive oyster mortality (Leatherman et al. 1995).

\subsection{Birds}

The bays and estuaries of the mid-Atlantic region provide important habitat for a variety of resident and migratory birds including the osprey, bald eagle, 6 species of colonially nesting waders (such as the great blue heron and snowy egret), and dozens of shorebird and waterfowl species. Chesapeake and Delaware Bays harbor the largest concentrations of migratory shorebirds in the western hemisphere. Approximately $70 \%$ of the entire North American population of the red knot Calidris canutus is in Delaware Bay at one time (Sutton et al. 1996). Chesapeake Bay is also used by nearly 1 million ducks, geese and swans to feed and rest during the winter months and thousands more use it as a migration stopover point. MAC birds utilize a diversity of wetland habitats within the region for feeding, consuming fish, amphibians, invertebrates, and SAV. Habitat loss and the effects of contaminants and declines in water quality on food resources have caused population declines of many of these species (Funderbunk et al. 1991). Changes in water temperature and quality under climate change will have mostly indirect effects on these species, primarily through changes in the distribution and abundance of food resources.

Waterfowl use of Chesapeake Bay has changed tremendously in the last $50 \mathrm{yr}$. Wintering population sizes of most duck species have declined steadily since the 1950s, while population sizes of Canada geese and snow geese have increased (Perry \& Deller 1996). M ost of these changes are attributed to changes in waterfowl food resources in and around the Bay, particularly the widespread decline of SAV (Perry \& Deller 1996). Projections of warming Bay waters, possible streamflow increases, and increasing coastal populations suggest that water quality and therefore SAV will continue to decline, leading to further declines in SAV-dependent waterfowl. Diving ducks and many other birds could also be negatively impacted by the anoxiainduced declines in shellfish noted earlier.

Factors outside the mid-Atlantic will likely play a role as well. For example, Sorenson et al. (1998, unpubl.) used the warmer and drier projections for the prairie pothole region of the north-central US and south-central Canada (the continent's 'duck factory') to infer that the number of pothole wetlands and, correspondingly, the number of ducks breeding in the region would be reduced. In turn, this could reduce waterfowl abundance in M AC waters because many of the ducks that winter there breed in the pothole region. Band recovery data for one of the most abundant ducks, the canvasback Aythya valisineria, show that approximately $40 \%$ (346/875) of canvasbacks breeding in the prairie pothole region winter in the Atlantic Flyway. Ninety-one percent (316/346) of the Atlantic Flyway population are found in MAC waters, $75 \%(236 / 316)$ of these on Chesapeake Bay. Declines in breeding population sizes of ducks in Prairie Canada ranging from 19 to $39 \%$ and 7 to $70 \%$ are projected for the 2030s and 2090s, respectively (Sorenson et al. unpubl. data). Declining breeding population sizes and fewer young produced under increasing drought conditions on the prairies coupled with likely declines in wintering habitat quality due to climate change bode poorly for future duck populations on MAC waters.

\section{SOCIETAL RESPONSES}

The coastal areas of the mid-Atlantic region have aesthetic and economic values. The shore is a tourist destination, inviting investment in facilities to serve the tourist population. For many coastal areas, visitors and temporary residents exceed the resident population by an order of magnitude or more. The annual flux of visitors to the coast is concentrated during the peak summer holiday but extends to the shoulder seasons in late spring and early fall, as well as weekends and holidays.

American society has, in general, subsidized coastal development with federal activities such as shoreline protection, beach replenishment, federal disaster assistance, and the National Flood Insurance Program (NFIP). Coastal counties of 4 mid-Atlantic states ( $\mathrm{New}$ J ersey, Delaware, Maryland, Virginia) had 177758 NFIP policies in effect with $\$ 21$ billion in coverage from 1978 to 1998 (H. J ohn Heinz III Center for Science, Economics and the Environment 1999). During that time, $\$ 81$ million in premium revenues were collected and $\$ 327$ million were paid in 46670 thousand claims, $\$ 138$ million (42\%) of which were repetitive. The Coastal Zone M anagement Act of 1972, in cooper- 
ation with state coastal agencies, provides measures to control development, and NFIP has strengthened regulations regarding the elevation of new or reconstructed buildings. However, NFIP regulations are enforced poorly in many areas. Furthermore, federal declarations of emergency, which make people eligible for financial assistance after storms, may only serve to encourage development.

\subsection{Potential impacts}

The potential impacts on development and use in the $M A C$ region are positive and negative. On the positive side, a warming of several ${ }^{\circ} \mathrm{C}$ (Table 1 ) would significantly extend the season of coastal recreation, giving seasons to the northerly areas that are as long as those now occurring in N orth Carolina and Virginia. On the negative side, there appear to be greater risks. Although the MAC region is not particularly vulnerable to hurricanes (with the exception of the Outer Banks of N orth Carolina), September is the most common period of direct hits ( arrell et al. 1992). Thus, an extension of the tourist season would result in a greater number of people potentially affected by hurricanes. The threats to the coasts from sea-level rise include long-term and sometimes subtle threats from coastal inundation and erosion. Immediate threats may occur from storms and tidal surges either greater in frequency and severity than in the past or imposed on higher water levels (Fig. 2). Wetlands loss due to sealevel rise and increased anoxia and habitat squeeze due to warming would negatively affect waterfowl hunting and sport and commercial fishing. If warming increases toxic algal blooms, decreased coastal tourism and fishing would likely result.

\subsection{M anagement and adaptation options}

Sea-level rise poses an important challenge to desirable coastal environments and beach-front developments. In estuaries, it is likely that protection from submergence will be accepted only for socially significant locations, and values of land development will largely determine areas to be protected by dikes or walls. Dry land will yield to wetlands and water where economic or cultural importance, or both, are not established. In Chesapeake Bay, with its numerous small cliffs, sealevel rise will directly increase erosion rates if other changes (e.g. increased bulkheading) do not occur. Response strategies will vary from state to state. North Carolina prohibits armoring of the open shoreline, while other states allow a wider range of responses. Titus (1998) documented rapidly increasing armoring of
Maryland's bay shores. Some communities will identify ecologically important areas and protect them, as is being tried in parts of the Blackwater Refuge in Maryland. Both protection and abandonment will exact a cost from society that will increase through time.

In general, we anticipate that in the ocean coastal areas, society will continue to support structural approaches such as beach replenishment, groins, and sea walls to maintain the status quo. Titus et al. (1985) estimated that the costs of maintaining the beachfront should be negligible over the next $40 \mathrm{yr}$, given the large amount of revenue that local tourism generates. Their calculations were based on sea-level rise scenarios close to the middle and high projections shown in Table 1. From these scenarios, sand requirements and their associated costs were computed. More recent studies using similar methods support the economic benefit of beach nourishment in Delaware (Faucett A ssociates 1998, Parsons \& Powell 1998). Nevertheless, Delaware has taken the stance of allowing strategic retreat for state-owned coastal lands. An emerging policy of beach replenishment in New Jersey has a potential cost of $\$ 60$ million mile $^{-1}$ and a $50 \mathrm{yr}$ total cost of $\$ 9$ billion (Grunwald 1999).

There are important legal dimensions to the process of beach retreat in coastal areas (Titus 1998). For example, if individual landowners are allowed to build seawalls to protect against beach erosion, the publicly accessible margin between high and low tide may eventually disappear. Titus (1998) argued for a rolling easement concept that would maintain public access to tidal lands as shorelines retreat, even beneath buildings raised above regulation flood levels. Acceptance of such a policy would require legislative action. Some degree of beach replenishment and shoreline hardening might be necessary to make such a policy seem less threatening to private property in the short run.

Inland flood losses and flood control investments in the US have increased with time. Settlement history and the development of federally subsidized transport systems and flood mitigation measures have encouraged floodplain occupancy. It has taken a century for US flood control policy to begin moving from structural approaches to non-structural approaches. Only in the last decade has there been serious consideration of relocating flood-prone communities and abandoning breached levees to re-establish normal river-floodplain relations. On the mid-Atlantic coast, if not elsewhere, one can foresee coastal management repeating the inland floodplain experience: federal subsidies for occupation of dynamic and sometimes hazardous coastal zones; structural answers to control coastal hazards and the impact of sea-level rise; and ever-increasing vulnerability with losses increasing along with investments in protection. 


\section{CONCLUSIONS AND RECOMMENDATIONS FOR FURTHER RESEARCH}

Informed speculation on how climate change may affect the mid-A tlantic coastal region can be based on information about past climate impacts on the region and climate model projections. Sea level, temperature, storminess and streamflow have had profound effects on the MAC region. Climate change has caused a progressive and significant increase in sea level over the past century, eroding shores and increasing stormrelated coastal flooding. Temperature variations have affected coastal ecosystems and fisheries by changing parasite-host relationships, and may also affect predator-prey relationships among other things. Streamflow variations have effectively dictated the seasonal and interannual variations in estuarine water quality. Past experience strongly suggests that mid-Atlantic climate change will significantly impact coastal waters. Table 3 presents a qualitative summary of what the impacts might be and how certain the predictions are. The ecological, and hence societal, impacts are largely negative. The only positive societal benefit is the potential for increased coastal tourism due to the warmer climate. Table 3 also presents the potential impacts on the MAC region of future population growth. These impacts tend to be in the same direction as the climate change impacts.

The high human population density of the MAC region has increased the sensitivity of the region to climate variability. For example, coastal inundation due to sea-level rise is exacerbated by human activities that reduce the supply of sediment, such as dam building and bulkheading. Coastal anoxia has probably always been sensitive to streamflow in many midAtlantic estuaries, like Chesapeake Bay (Cooper \& Brush 1991), but nutrient inputs due to human activity have probably heightened this sensitivity (Walker et al. 2000). Thus, climatic and human influences act synergistically on the MAC region. We speculate that climate may indirectly impact the MAC region in the future through warminginduced human migration to the coast. This could compound effects on water quality and sea-level rise, as suggested in Fig. 3. One management implication of our study, therefore, is that policies designed to reduce adverse environmental impacts of local human activities could help mitigate some of the risks associated with climate-change.

The capability of predicting the environmental impacts of future climate change on the MAC region is influenced by 2 factors: (1) our ability to predict how the regional climate will change and (2) our understanding of the sensitivity of the region to climate change. Predictions for sea-level rise and temperature change have much greater certainty than predictions for other aspects of climate variability. There is a large body of work published on global sea-level rise (Warrick et al. 1996, and references therein), and on RSLR in Chesapeake Bay and its likely consequences (Kearney \& Stevenson 1991, Downs et al. 1994, Wray et al. 1995). There is substantially greater uncertainty concerning past and future changes in extreme weather events, variability in regional precipitation, and streamflow, all of which have the potential for substantial impacts in the coastal zone. $M$ ore research is clearly needed in these areas.

Though there is abundant evidence that ecosystems in the MAC region are sensitive to climate, the mechanisms are not well understood; this makes prediction of the impacts of climate change unreliable, even if the future climate could be predicted with certainty. We recommend a 4-pronged approach to understanding the sensitivity of MAC ecosystems to climate, and to help distinguish between effects of climate variability and other anthropogenic components of change: (1) increased monitoring and historical data analysis; (2) experimental manipulation of the environment (temperature, salinity, $\mathrm{CO}_{2}$, etc.) in the laboratory and field to test specific hypothesis concerning ecosystem sensitivity; (3) measurement and analysis of paleo-climate variability (from caves, tree rings, marine sediment cores, etc.) to increase our understanding of decadalscale changes in regional climate, in the context of larger spatial-scale variability in the northern hemisphere during the Holocene; and (4) numerical modeling of the impact of climate on physical, chemical and biological processes.

There are a number of important unknowns with regard to the societal impacts of climate change in the MAC region. Research attempting to quantify the effect of increased temperatures on human migration to the coast would be extremely helpful. Mapping is

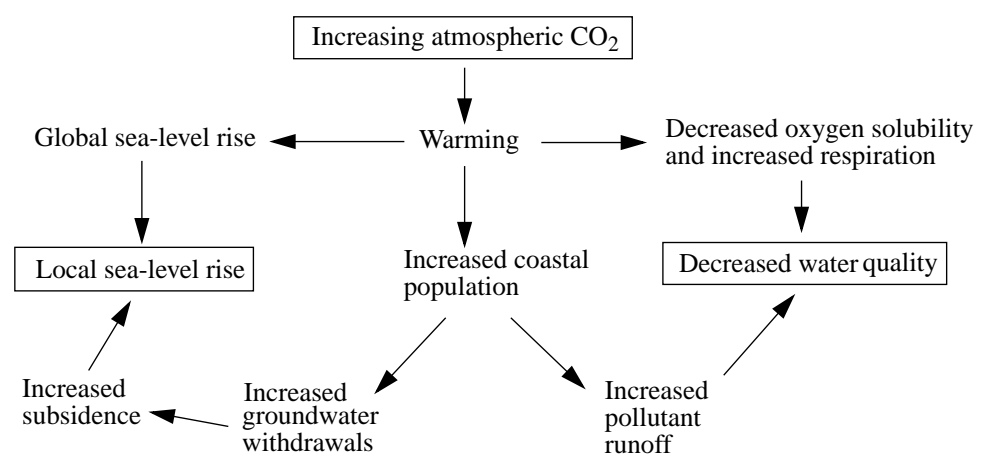

Fig. 3. Schematic showing possible synergistic impacts of climate change and coastal development on sea-level rise and water quality 


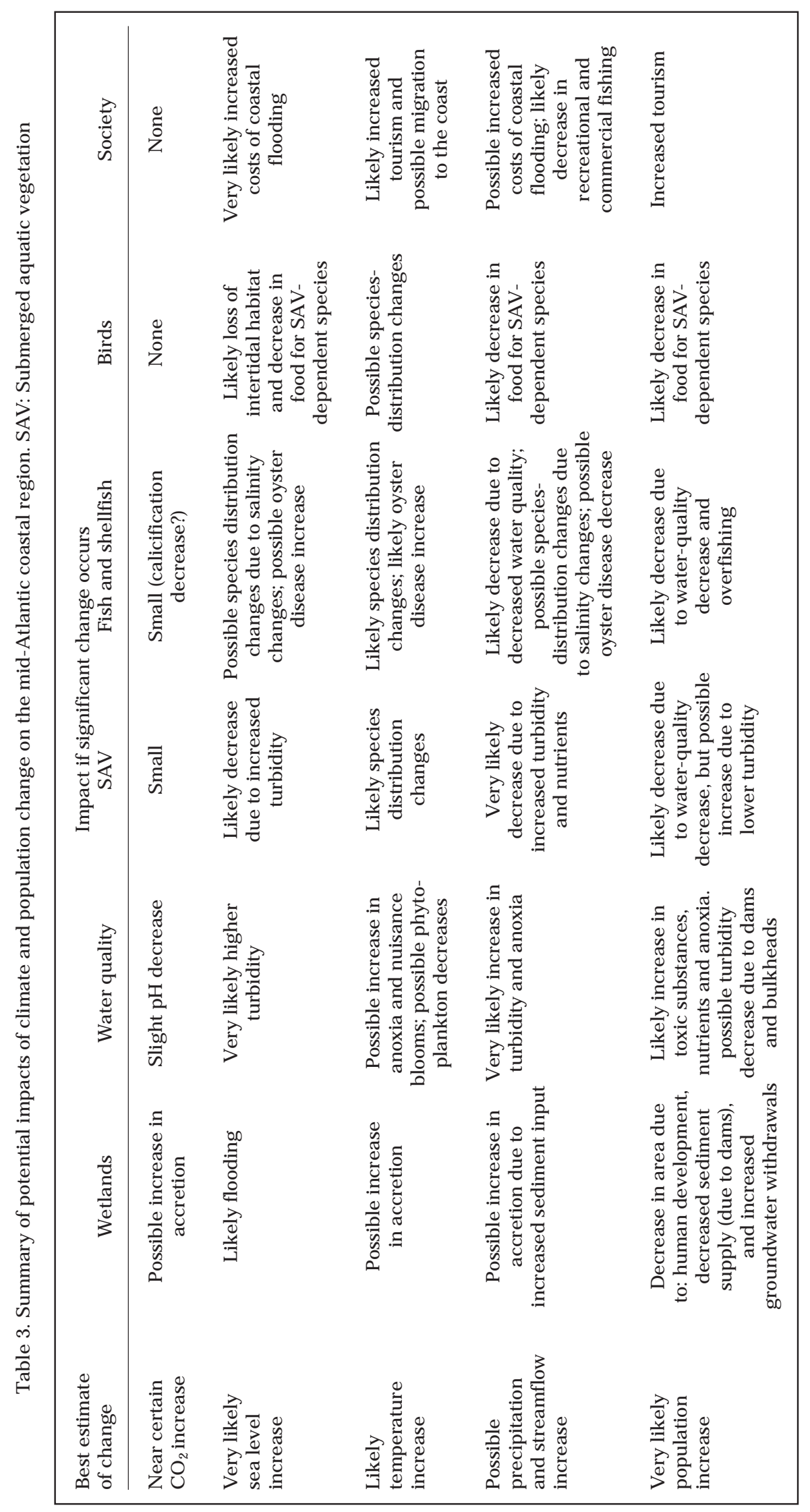


needed of coastal regions that are most economically vulnerable to climate change, particularly to sea-level rise. Finally, research into the long-term costs and benefits of federal subsidies and shoreline protection methods would be most helpful in guiding future public policy for the mid-Atlantic coastal region.

Acknowledgements. We thank Robert Nicholls, who provided a detailed review that greatly improved the manuscript. Helpful comments by Don Boesch, Dan Campbell, Ann Fisher, Suzanne Lussier, Candace Oviatt and an anonymous reviewer are appreciated. Thanks also to Michael Siegel for drafting assistance. This work was funded by the US Environmental Protection Agency under a cooperative agreement with the Environmental Resources Research Institute of The Pennsylvania State University, CR 826554. Contribution No. NHEERL-NAR-2125. Contribution Number 3258 from the University of Maryland Center for Environmental Science. Mention of trade names or commercial products does not constitute endorsement or recommendation for use by US EPA.

\section{LITERATURE CITED}

Barry J P, Baxter CH, Sagarin RD, Gilman SE (1995) Climaterelated, long-term faunal changes in a California rocky intertidal community. Science 267:672-675

Boer GJ , M cFarlane NA, Laprise R, Henderson J D, Blanchet J P (1984) The Canadian Climate Centre spectral atmospheric general circulation model. Atmos Ocean 22: 397-429

Boer GJ , McFarlane N, Lazare M (1992) Greenhouse gas induced climate change simulated with the CCC second generation GCM . J Clim 5:1045-1077

Boer GJ , Flato GM, Reader M C, Ramsden D (2000a) A transient climate change simulation with greenhouse gas and aerosol forcing: experimental design and comparison with the instrumental record for the 20th century. Clim Dyn (in press)

Boer GJ , Flato GM, Ramsden D (2000b) A transient climate change simulation with greenhouse gas and aerosol forcing: projected climate for the 21st century. Clim Dyn (in press)

Bricker-Urso S, Nixon SW, Cochran J K, Hirschberg DJ , Hunt C (1989) Accretion rates and sediment accumulation in Rhode Island salt marshes. Estuaries 12:300-317

Bruun P (1988) The Bruun Rule of erosion by sea-level rise: a discussion on large-scale two- and three-dimensional usages. J Coast Res 4:627-648

Cahoon DR, Reed J W, Day J W J r (1995) Estimating shallow subsidence in microtidal saltmarshes of the southeastern United States: Kaye and Barghoorn revisited. Mar Geol 128:1-9

Callaway J C, Nyman J A, DeLaune RD (1996) Sediment accretion in coastal wetlands: a review and a simulation model of processes. Curr Topics Wetland Biogeochem 2:2-23

Cook T, Folli M, Klinck J , Ford S, Miller J (1998) The relationship between increasing sea-surface temperature and the northward spread of Perkinsus marinus (Dermo) disease epizootics in oysters. Estuar Coast Shelf Sci 46:587-597

Cooper SR, Brush GS (1991) Long-term history of Chesapeake Bay anoxia. Science 254:992-996

Coutant CC (1990) Temperature-oxygen habitat for freshwater and coastal striped bass in a changing climate. Trans Am Fish Soc 119:240-253
Crane RG, Hewitson BC (1998) Doubled $\mathrm{CO}_{2}$ precipitation changes for the Susquehanna Basin: downscaling from the Genesis general circulation model. Int J Climatol 18:65-76

Douglas BC (1991) Global sea-level rise. J Geophy Res 96: 6981-6992

Downs LL, Nicholls RJ, Leatherman SP, Hautzenroder J (1994) Historic evolution of a marsh island: Bloodsworth Island, Maryland. J Coast Res 10:1031-1044

Drake BG, Peresta G, Beugeling E, M atamala R (1996) Longterm elevated $\mathrm{CO}_{2}$ exposure in a Chesapeake Bay wetland: ecosystem gas exchange, primary production, and tissue nitrogen. In: Koch GW, Mooney HA (eds) Carbon dioxide and terrestrial ecosystems. Academic Press, San Diego, CA, p 197-214

Faucett Associates (1998) The economic effects of a five-year nourishment program for the ocean beaches of Delaware. Report for The Beach Replenishment Task Force, State of Delaware

Fisher A, N eff R, Barron EJ (2000) The Mid-Atlantic Regional Assessment: motivation and approach. Clim Res 14: 153-159

Flato GM, Boer GJ, Lee WG, McFarlane NA, Ramsden D, Weaver AJ (2000) The CCCma global coupled model and its climate. Clim Dyn (in press)

Funderbunk SL, J ordan SJ , Mihursky J A, Riley D (eds) (1991) Habitat requirements for Chesapeake Bay living resources, 2nd edn. Chesapeake Research Consortium, Inc, Solomons, MD

Grunwald M (1999) Fixing the beach, for $\$ 60$ million a mile. Washington Post, A pril 19, p A3

H. J ohn Heinz III Center for Science, Economics and the Environment (1999) The hidden costs of coastal hazards: implications for risk assessment and mitigation. Island Press, Covelo, CA

Harding LW, Perry ES (1997) Long-term increase of phytoplankton biomass in Chesapeake Bay, 1950-1994. Mar Ecol Prog Ser 157:39-52

Harvell CD, Kim K, Burkholder J M, Colwell RR, Epstein PR, Grimes DJ, Hofmann EE, Lipp EK, Osterhaus ADME, Overstreet RM, Porter J W, Smith GW, Vasta GR (1999) Emerging marine diseases-climate links and anthropogenic factors. Science 285:1505-1510

Hodny J W (1992) Climate change and water resources within the Delaware River and Delmarva Regions. Masters thesis, Department of Geography, University of Delaware, Newark

Houghton J T, Meira Filho LG, Callander BA, Harris N, Kattenberg A, Maskell K (1996) Climate change 1995: the science of climate change. Cambridge University Press, Cambridge

Hull CHJ , Titus J G (1986) Greenhouse effect, sea-level rise, and salinity in the Delaware Estuary. US EPA 230-05-86010, US Environmental Protection Agency and the Delaware River Basin Commission, Washington, DC

Hurley LM (1991) Submerged aquatic vegetation. In: Funderbunk SL, J ordan SJ , Mihursky J A, Riley D (eds) Habitat requirements for Chesapeake Bay living resources, 2nd edn. Chesapeake Research Consortium, Inc, Solomons, MD, p 2-1-2-19

J arrell J D, Hebert PJ , Mayfield M (1992) Hurricane experience levels of coastal county populations from Texas to Maine. NOAA Technical Memorandum NWS NHC-46 (August). National Hurricane Center, Coral Gables, FL

J ohns TC, Carnell RE, Crossley J F, Gregory J M , M itchell J FB, Senior CA, Tett SFB, Wood RA (1997) The second Hadley Centre coupled ocean-atmosphere GCM : model description, spinup and validation. Clim Dyn 13:103-134 
Kearney MS, Stevenson J C (1991) Island land loss and marsh vertical accretion rate evidence for historical sea-level changes in Chesapeake Bay. J Coast Res 7:403-415

Keller AA, Oviatt CA, Walker HA, Hawk J D (1999) Predicted impacts of elevated temperature on the magnitude of the winter-spring phytoplankton bloom in temperate coastal waters: a mesocosm study. Limnol Oceanogr 44:344-356

Kennedy VS (1990) Anticipated effects of climate change on estuarine and coastal fisheries. Fisheries 15(6):16-24

Kennedy VS, Breisch LL (1981) Maryland's oysters: research and management. M aryland Sea Grant Publications UM SG-TS-81-04, University of Maryland, College Park, MD

Leatherman SP, Chalfont R, Pendleton EC, McCandless TL, Funderburk S (1995) Vanishing lands: sea level, society and Chesapeake Bay. University of M aryland and US Fish and Wildlife Service, Annapolis, MD

McCabe GJ , Ayers MA (1989) Hydrologic effects of climate change in the Delaware River Basin. Water Resour Bull 25: 1231-1242

M cFarlane NA, Boer GJ, Blanchet J P, Lazare M (1992) The Canadian Climate Centre second-generation general circulation model and its equilibrium climate. J Clim 5: 1013-1044

Meade RH (1982) Sources, sinks, and storage of river sediment in the drainage of the United States. J Geol 90: 235-252

Mitchell JFB, Johns TC (1997) On modification of global warming by sulfate aerosols. J Clim 10:245-267

Mitchell J FB, J ohns TC, Gregory J M, Tett S (1995) Climate response to increasing levels of greenhouse gases and sulphate aerosols. Nature 376:501-504

M oore MV, Pace ML, M ather J R, M urdoch PS, Howarth RW, Folt CL, Chen CY, Hemond HF, Flebbe PA, Driscoll CT (1997) Potential effects of climate change on freshwater ecosystems of the New England/Mid-Atlantic Region. Hydrol Processes 11:925-947

Moorhead KK, Brinson MM (1995) Response of wetlands to rising sea level in the lower coastal plain of North Carolina. Ecol Appl 5:261-271

M urawski SA (1993) Climate change and marine fish distributions: forecasting from historical analogy. Trans Am Fish Soc 122:647-658

Najjar RG (1999) The water balance of the Susquehanna River Basin and its response to climate change. J Hydrol 219:7-19

N eff R, Chang H, Knight CG, Najjar RG, Yarnal B, Walker HA (2000) Impact of climate variation and change on MidAtlantic Region hydrology and water resources. Clim Res $14: 207-218$

Nicholls RJ , Leatherman SP (1996) Adapting to sea-level rise: relative sea-level trends to 2100 for the United States. Coast M anage 24:301-324

Niering WA, Warren RS (1980) Vegetation patterns and processes in New England salt marshes. BioScience 30:301-307

NOAA (1997a) NOAA's estuarine eutrophication survey, Vol 1: South Atlantic Region. Office of Ocean Resources Conservation and Assessment, National Oceanic and Atmospheric Administration, Silver Spring, MD

NOAA (1997b) NOAA's estuarine eutrophication survey, Volume 2: Mid-Atlantic Region. Office of Ocean Resources Conservation and Assessment, National Oceanic and Atmospheric Administration, Silver Spring, MD

Officer CB, Biggs RB, Taft J L, Cronin LE, Tyler M A, Boynton WR (1984) Chesapeake Bay anoxia: origin, development and significance. Science 223:22-27

Parsons GR, Powell M (1998) The cost of beach retreat: a hedonic price analysis of Delaware beaches. Department of Economics Working Paper 98-14, University of Delaware, Newark

Parsons PA (1990) The metabolic cost of multiple environmental stresses: implications for climatic change and conservation. Trends Ecol Evol 5:315-317

Perry MC, Deller AS (1996) Review of factors affecting the distribution and abundance of waterfowl in shallow-water habitats of Chesapeake Bay. Estuaries 19:272-278

Polsky C, Allard J, Currit N, Crane R, Yarnal B (2000) The Mid-Atlantic Region and its climate: past, present and future. Clim Res 14:161-173

Psuty NP (1992) Estuaries: challenges for coastal management. In: Fabbri P (ed) Ocean management in global change. Elsevier A pplied Science, London, p 502-518

Psuty NP, Collins D (1996) Sea-level rise: a white paper on the measurements of sea-level rise and a perspective on the implications for management. Institute of Marine and Coastal Sciences, Rutgers University, New Brunswick, NJ

Sanford E (1999) Regulation of keystone predation by small changes in ocean temperature. Science 283:2095-2097

Seliger HH, Boggs J A (1988) Long term pattern of anoxia in the Chesapeake Bay. In: Lynch MP, Kronme EC (eds) Understanding the estuary: advances in Chesapeake Bay research. Publication 129. Ref. CBP/TRS 24/88, Chesapeake Research Consortium, Gloucester Point, VA, p 570-583

Seliger HH, Boggs J A, Biggley WH (1985) Catastrophic anoxia in the Chesapeake Bay in 1984. Science 228:70-73

Sorenson LG, Goldberg R, Root TL, Anderson MG (1998) Potential effects of global warming on waterfowl populations breeding in the N orthern Great Plains. Clim Change 40:343-369

Stevenson J C, Ward LG, Kearney MS (1988) Sediment transport and trapping in marsh systems: implications of tidal flux studies. Mar Geol 80:37-59

Sutton CC, O Herron J C II, Zappalorti RT (1996) The scientific characterization of the Delaware Estuary. (DRBC Project No. 321, HA File No. 93.21, The Delaware Estuary Program, Herpetological Associates, Inc, Forked River, NJ )

Tester PA (1996) Climate change and marine phytoplankton. Ecosyst Health 2(3):191-197

Titus J G (1998) Rising seas, coastal erosion, and the takings clause: how to save wetlands and beaches without hurting property owners. Maryland Law Rev 57:1279-1399

Titus J G, Narayanan V (1995) The probability of sea-level rise. US EPA 230-R-95-008. US Environmental Protection Agency, Office of Policy, Planning, and Evaluation, Climate Change Division, Washington, DC

Titus J G, Leatherman SP, Everts C, Kriebel D, Dean R (1985) Potential impacts of sea level rise on the beach at Ocean City, Maryland. US EPA document EPA 230-10-85-013, US EPA, Washington, DC (accessed November 15, 1999); available at http://www.epa.gov/globalwarming/reports/ pubs/sealevel/ oceancity/index.html

Trimble SW (1974) Man-induced soil erosion on the southern Piedmont 1700-1970. Soil Conservation Society of America, Ankeny, IA

US EPA (1998) Condition of the Mid-Atlantic estuaries. US EPA 600-R-98-147, Environmental Protection Agency, Office of Research and Development, Washington, DC

USGS (1999a) 7.5-minute digital elevation model data. United States Geological Survey, Reston, VA (accessed: November 15, 1999); available at http://edc.usgs.gov/glis/hyper/ guide/ 7_min_dem\#/m11

USGS (1999) United States Geological Survey, Reston, VA (accessed: N ovember 15, 1999); available at http://edc.usgs.gov/glis/ 
hyper/guide/ mrlc

Walker HA, Latimer J S, Dettmann EH (2000) Assessing the effects of natural and anthropogenic stressors in the Potomac Estuary: implications for long-term monitoring. Environ M onit Assess (in press)

Walker HJ, Coleman JM (1987) Atlantic and Gulf coastal province. In: Graf WL (ed) Geomorphic systems of North America, Centennial Special Vol 2. Geological Society of America, Boulder, CO, p 51-110

Warrick RA, Le Provost C, Meier MF, Oerlemans J, Woodworth PL (1996) Changes in sea level In: Houghton JT, Meira Filho LG, Callander BA, Harris N, Kattenberg A, Maskell K (eds) Climate change 1995: the science of cli- mate change. Cambridge University Press, Cambridge, p 359-405

Wigley TML, Jones PD (1985) Influences of precipitation changes and direct $\mathrm{CO}_{2}$ effects on streamflow. Nature 314: 149-152

Williams RG, Godshall FA (1977) Summarization and interpretation of historical physical oceanographic and meteorological information for the mid-Atlantic region. US Department of Commerce, Washington, DC

Wray RD, Leatherman SP, Nicholls RJ (1995) Historic and future land loss for upland and marsh islands in the Chesapeake Bay, Maryland, US. J Coast Res 11: 1195-1203 